\title{
Genetic associations of test-day fat:protein ratio with milk yield, fertility, and udder health traits in Nordic Red cattle
}

\author{
E. Negussie, ${ }^{1}$ I. Strandén, and E. A. Mäntysaari \\ MTT Agrifood Research, Biotechnology and Food Research, Biometrical Genetics, 31600 Jokioinen, Finland
}

\begin{abstract}
Interest is growing in finding indicator traits for the evaluation of nutritional or tissue energy status of animals directly at the individual animal level. The development and subsequent use of such traits in practice demands a clear understanding of the genetic and phenotypic associations with the various production and functional traits. In this study, the relationships during lactation between milk fat:protein ratio (FPR) and production and functional traits were estimated for Nordic Red cattle, in which published information is scarce. The objectives of this study were to estimate genetic associations of FPR with milk yield (MY), fertility, and udder health traits during different stages of lactation. Traits included in the analyses were MY, 4 fertility traits - days from calving to insemination (DFI), days open (DO), number of inseminations (NI), and nonreturn rate to $56 \mathrm{~d}(\mathrm{NRR})$ - and 2 udder health traits - test-day somatic cell score (SCS) and clinical mastitis (CM). Data were from a total of 22,422 firstlactation cows. Random regression models were used to estimate genetic parameters and associations between traits. The mean FPR in first-lactation cows was 1.28 and ranged from 1.25 to 1.45. During first lactation, the heritability of FPR ranged from 0.14 to 0.25 . Genetic correlations between FPR and MY in early lactation (until $50 \mathrm{~d}$ in milk) were positive and ranged from 0.05 to 0.22 ; later in lactation, they were close to zero or negative, indicating that cows may have come out of the negative state of energy balance. The strength of genetic associations between FPR and fertility traits varied during lactation. In early lactation, correlations between FPR and the interval fertility traits DFI and DO were positive and ranged from 0.14 to 0.28 . Genetic correlations between FPR and the udder health traits SCS and CM in early lactation ranged from 0.09 to 0.20 . Milk fat:protein ratio is a heritable trait and easily available from routine milk-recording schemes. It can be used as a low-cost monitoring tool of poor
\end{abstract}

Received May 12, 2012.

Accepted October 29, 2012.

${ }^{1}$ Corresponding author: enyew.negussie@mtt.fi health and fertility in the most critical phases of lactation and as an important indicator trait to improve robustness in dairy cows through selection.

Key words: milk fat:protein ratio, functional trait, genetic correlation, random regression

\section{INTRODUCTION}

Genetic improvement over the years has markedly increased milk yield (MY) in dairy cows. Milk yield per cow has more than doubled in the last $40 \mathrm{yr}$, and many cows now produce more than $20,000 \mathrm{~kg}$ of milk per lactation (Sonstegard et al., 2001; Oltenacu and Broom, 2010). This increase in production, however, is associated with reduced fertility and increased health problems (Butler and Smith, 1989; Collard et al., 2000; de Vries and Veerkamp, 2000; Oikonomou et al., 2008). In particular, during early lactation, dietary intake of cows fails to keep pace with the demand for peak milk production (Bauman and Currie, 1980), leading to negative energy balance (NEB), which has serious consequences on other body functions (Pryce and Veerkamp, 2001; Banos et al., 2006; Friggens et al., 2007; Løvendahl et al., 2010). Energy balance (EB) can be calculated as the difference between energy intake and estimated energy requirements for milk output and maintenance as a function of live weight (Buttchereit et al., 2010); a negative state of $\mathrm{EB}$ is detrimental to cows' health and fertility. Breeding schemes designed to improve the milk production potential of dairy cows should be accompanied by means of monitoring and safeguards to prevent the deterioration of cows' health and fertility. This calls for a low-cost and practical means of monitoring tissue EB in dairy cows, particularly during the most critical phases of lactation.

In practice, monitoring EB requires regular measurement of feed intake and other production component variables in individual cows. These are expensive to measure in large populations (Berry et al., 2003; Løvendahl et al., 2010; Thorup et al., 2012) and particularly unfeasible in commercial dairy operations. Therefore, interest exists in finding other traits that could serve as indicators of EB (Coffey et al., 2001). So far, several traits and blood biochemical compounds (metabolites) 
have been considered (Miksa et al., 2004; Konigsson et al., 2008). Body condition score is one of these measures (de Vries and Veerkamp, 2000; Pryce and Veerkamp, 2001, Veerkamp et al., 2001) and it is widely used in many species to assess body composition and energy status of animals. Body condition score is a subjective measure and interest in the trait is growing in several countries (de Vries and Veerkamp, 2000; Loker et al., 2011).

During early lactation, postpartum lipolysis results in increasing fat percentage. This is coupled with a decrease in protein percentage because of inadequate intake of fermentable energy-spending carbohydrates, resulting in insufficient protein synthesis by ruminal bacteria (Gürtler and Schweigert, 2005), which leads to the marked changes in milk component ratios that are typical of this critical phase of a cow's lactation. This biological relationship between tissue mobilization and changes in milk component ratios, particularly that of the milk fat:protein ratio (FPR), could be used as an indicator of a cow's tissue energy status (Heuer et al., 1999) and its susceptibility to health and fertility problems.

In contrast to other measures of EB such as blood metabolites, which are invasive, difficult, and expensive to measure, MY and milk composition data are available in almost all milk-recorded herds. The use of milk compositional data to identify between-cow variations in EB could therefore be a low-cost alternative to measuring blood metabolites or feed intake. For this, it is essential to assess the genetic associations between milk component ratios and the various fertility and udder health traits that are sensitive to tissue EB during different stages of the whole lactation.

Several studies have reported the relationships between early-lactation milk composition and changes in health and fertility associated with NEB at the phenotypic level (Von Farries, 1983; Grieve et al., 1986; Butler and Smith, 1989; Loeffler et al., 1999). Kaufmann (1979) illustrated a positive association between milk protein percentage in early lactation and fertility of cows, which may be attributed to the relationship of milk protein to energy supply. Reid and Roberts (1983) reported reduced reproductive performance in cows with fatty liver after calving, a condition associated with the generalized fat mobilization syndrome that occurs in response to energy deficit in early lactation. Grieve et al. (1986) suggested that FPR is negatively related to EB and Loeffler et al. (1999) indicated that a change in FPR and milk fat percentage during early lactation had a negative effect on conception at first insemination. Friggens et al. (2007) assessed the use of various milk composition measures to predict $\mathrm{EB}$ in dairy cows. They reported that a reduced model with only 6 variables, including FPR and dFPR (difference as current minus the previous value of FPR), DIM, milk fat and lactose contents, and fat:lactose ratios, explained about $94 \%$ of the variation in EB with only $0.071 \mathrm{MJ} / \mathrm{d}$ more in prediction error compared with a 25-variable model.

Recently, Buttchereit et al. (2011, 2012) reported genetic associations between FPR and EB and some health traits in German Holsteins. They estimated genetic correlations between FPR and EB and between FPR and BCS ranging from -0.5 to -0.62 and from 0.17 to 0.19 , respectively, and concluded that in early lactation, FPR can be an adequate measure of EB. Jamrozik and Schaeffer (2012) considered FPR as an indicator of subclinical mastitis in first-lactation Canadian Holsteins. Nevertheless, FPR has so far received relatively little attention in genetic studies of dairy cattle and, hence, estimates of genetic parameters are generally scarce (Buttchereit et al., 2012; Jamrozik and Schaeffer, 2012). In particular, literature is lacking on estimates of genetic variation and genetic associations between FPR and udder health and fertility traits involving the Nordic Red cattle. Furthermore, most studies to date have been based on data from experimental herds, often including a small data set. Genetic analyses that used data from a routine milk recording scheme, including a large number of cows, and modeling the entire lactation are lacking. The objectives of this study were to estimate the genetic associations of test-day FPR with MY and cow fertility and udder health traits during different stages of lactation using random regression models (RRM).

\section{MATERIALS AND METHODS}

\section{Data and Trait Definition}

Records on test-day milk, protein, and fat yields, as well as fertility and udder health traits of first-lactation cows calving during years from 1990 to 2006 were provided by the Finnish Animal Breeders Association (Faba, Vantaa, Finland). Data used were from randomly selected herds with at least 25 cows with complete udder health and fertility records. Test-day FPR was calculated for all test-days during lactation for cows with at least 2 test-day records for fat and protein yield.

Fertility traits included were number of inseminations (NI) in service period, days from calving to first insemination (DFI), nonreturn rate to $56 \mathrm{~d}$ after first insemination (NRR), and days open (DO) as the number of days from calving to successful conception. In addition, the data included 2 udder health traits: test-day SCS, and clinical mastitis (CM). Somatic cell score was expressed as $\log _{\mathrm{e}}$-transformed SCC $\left(\log _{\mathrm{e}} \mathrm{SCC}\right)$ 
Table 1. Description of the data used for this study

\begin{tabular}{lcc}
\hline Trait & $\begin{array}{c}\text { Observations } \\
\text { (no.) }\end{array}$ & $\begin{array}{c}\text { Mean } \\
\text { (SD) }\end{array}$ \\
\hline Calving to first insemination (d) & 22,422 & $84.1(27)$ \\
Days open (d) & 22,422 & $124.7(62)$ \\
Number of inseminations (no.) & 22,102 & $1.98(1.19)$ \\
Nonreturn rate to 56 d (\%) & 22,102 & $0.55(0.49)$ \\
Clinical mastitis (\%) & 21,560 & 13.0 \\
SCS [ln(SCC/1,000)] & 77,945 & $4.04(1.20)$ \\
Milk yield (kg & 105,028 & $21.3(4.89)$ \\
Protein yield (\%) & 76,452 & $0.72(0.14)$ \\
Fat yield (\%) & 76,452 & $0.92(0.21)$ \\
Fat:protein ratio & 76,452 & $1.29(0.21)$ \\
\hline
\end{tabular}

from monthly test days measured in 1,000 cells $/ \mathrm{mL}$. Clinical mastitis was defined as a binary trait covering the interval $10 \mathrm{~d}$ before to $350 \mathrm{~d}$ after first calving. Within this interval, the absence or presence of mastitis was scored as "0" or "1," respectively, based on veterinary treatment of a cow for CM. A cow was considered to have had mastitis if at least one veterinary treatment was recorded or a cow was culled for mastitis reasons within this interval. A test-day record comprised observations on test-day MY, fat, protein, SCS, and FPR recorded within 8 to 365 DIM. The data included 22,422 cows with records. A sire model was used, and the sire pedigree had 1,402 males, of which 509 had daughters with data. Detailed descriptions of the data are given in Table 1.

\section{Data Analysis}

Model. Initially, univariate analyses of MY, FPR, and SCS were made to determine the appropriate order of Legendre polynomials for modeling test-day traits. The appropriate order of Legendre polynomials was selected by fitting different RRM with varying orders of Legendre polynomials. At each step, the log-likelihoods, estimates of residual variances, and eigenvalues of the additive genetic covariance matrices were analyzed to assess the importance of adding further parameters. Bivariate analyses were then used to estimate the genetic and phenotypic associations between FPR and the different production, fertility, and udder health traits. In the bivariate analyses with the test-day FPR, the sire additive genetic and permanent environmental effects for the test-day traits were modeled by second-order orthogonal Legendre polynomials. For DFI, DO, NI, NRR, and CM, only the intercept term was fitted. The modeling of fixed effects for the test-day traits included age at calving, calving year $\times$ calving month, and fixed lactation curve. In the model for the fertility and CM traits, the fixed effects included were the same as for the test-day traits with the exception of the lactation curve and calving year $\times$ calving month, which was replaced by calving month $(\mathbf{c m})$ for fertility traits and by herd-year (hy) for CM. The fixed lactation curve was modeled only for the test-day traits by third-order Legendre polynomials and a Wilmink term. A model used for a univariate fertility or CM trait analysis was

$$
y_{T_{h i j n t}}=a g_{T_{h}}+y m_{T_{i}}+h y_{T_{j}}+a_{T_{n}}+e_{T_{h i j n t}},
$$

where $y_{T}$ are observations on fertility or CM, in calving year $\times$ month $(y m) i$ [calving month $(\mathrm{cm})$ for fertility traits), herd-year of calving ( $h y) j$, on a cow belonging to the calving age class $h, a_{n}$ is additive genetic effect of sire $n$, and $e_{T_{h i j n t}}$ is the random residual. The same model was used for the other fertility traits in a singletrait model analysis.

The bivariate RRM for test-day FPR and a fertility or CM trait (model I) was

$$
\begin{aligned}
{\left[\begin{array}{l}
y_{F P R_{h i j k l m n t}} \\
y_{T_{h i j k m n t}}
\end{array}\right] } & =\left[\begin{array}{l}
a g_{F P R_{h}} \\
a g_{T_{h}}
\end{array}\right]+\left[\begin{array}{l}
y m_{F P R_{i}} \\
c m_{T_{i}}
\end{array}\right]+\left[\begin{array}{l}
h y_{F P R_{j}} \\
h y_{T_{j}}
\end{array}\right] \\
& +\left[\begin{array}{l}
\sum_{r=0}^{4} \boldsymbol{\varphi}_{\pi}(d)_{r} b_{F P R_{k}} \\
0
\end{array}\right]+\left[\begin{array}{c}
h t d_{F P R_{l}} \\
0
\end{array}\right] \\
& +\left[\begin{array}{l}
\sum_{r=0}^{2} \boldsymbol{\varphi}_{\alpha}(d)_{r} p_{F P R_{m}} \\
p_{T_{m}}
\end{array}\right]+\left[\begin{array}{l}
\sum_{r=0}^{2} \boldsymbol{\varphi}_{\alpha}(d)_{r} a_{F P R_{n}} \\
a_{T_{n}}
\end{array}\right] \\
& +\left[\begin{array}{l}
e_{F P R_{h i j k l m n t}} \\
e_{T_{h i j k m n t}}
\end{array}\right],
\end{aligned}
$$

where $y_{F P R}$ and $y_{T}$ are test-day FPR observations and lactation-wise observations on fertility or CM, respectively, recorded in herd test-day $(h t d) l$, in calving year $\times$ month $(y m) i$ [calving month $(\mathrm{cm})$ for fertility traits], herd-year of calving $(h y) j$, on a cow $m$ belonging to the calving age class $h$, calving-year $\times$ calving-season class 
$k$, and measured on DIM $d, b$ is fixed regressions describing the shape of the lactation curve, $p_{m}$ is permanent environmental effect (vector of random regression coefficients of permanent environmental effect within cow $m$ for test-day traits), $a_{n}$ is additive genetic effect of sire $n$ (vector of random regression coefficients of additive genetic effect of sire $n$ for test-day traits), and $e$ is the random residual.

The description of the bivariate RRM for test-day FPR and SCS (model II) was

$$
\begin{aligned}
{\left[\begin{array}{l}
y_{F P R_{h i j k l m n t}} \\
y_{S C S_{h i j k l m n t}}
\end{array}\right] } & =\left[\begin{array}{l}
a g_{F P R_{h}} \\
a g_{S C S_{h}}
\end{array}\right]+\left[\begin{array}{l}
y m_{F P R_{i}} \\
y m_{S C S_{i}}
\end{array}\right]+\left[\begin{array}{c}
h y_{F P R_{j}} \\
h y_{S C S_{j}}
\end{array}\right] \\
& +\left[\begin{array}{l}
\sum_{r=0}^{4} \boldsymbol{\varphi}_{\pi}(d)_{r} b_{F P R_{k}} \\
4 \\
\sum_{r=0}^{4} \boldsymbol{\varphi}_{\pi}(d)_{r} b_{S C S_{k}}
\end{array}\right]+\left[\begin{array}{l}
h t d_{F P R_{l}} \\
h t d_{S C S_{l}}
\end{array}\right] \\
& +\left[\begin{array}{l}
\sum_{r=0}^{2} \boldsymbol{\varphi}_{\alpha}(d)_{r} p_{F P R_{m}} \\
\sum_{r=0}^{2} \boldsymbol{\varphi}_{\alpha}(d)_{r} p_{S C S_{m}}
\end{array}\right]+\left[\begin{array}{l}
\sum_{r=0}^{2} \boldsymbol{\varphi}_{\alpha}(d)_{r} a_{F P R_{n}} \\
\sum_{r=0}^{2} \boldsymbol{\varphi}_{\alpha}(d)_{r} a_{S C S_{n}}
\end{array}\right] \\
& +\left[\begin{array}{l}
e_{F P R_{h i j k l m n t}} \\
e_{S C S_{h i j k l m n t}}
\end{array}\right],
\end{aligned}
$$

where $y_{F P R}$ and $y_{S C S}$ are test-day FPR and SCS observations, respectively, recorded in herd test-day $(h t d) l$, in calving year $\times$ month $(y m) i$, herd-year of calving (hy) $j$, on a cow $m$ belonging to the calving age class $h$, calving-year $\times$ calving-season class $k$, and measured on DIM $d, b$ is a fixed regression describing the shape of the lactation curve, $p_{m}$ is vector of random regression coefficients of permanent environmental effect within cow $m, a_{n}$ is vector of random regression coefficients of additive genetic effect of sire $n$, and $e$ is the random residual. The same model was used for the bivariate analyses of test-day FPR and MY.

The covariables for coefficients $b_{. r}(r=0, \ldots, 4)$ were

$$
\boldsymbol{\varphi}_{\pi}(d)=\left[\begin{array}{lllll}
c_{0} & c_{1} & c_{2} & c_{3} & \exp (w d)
\end{array}\right]^{\prime},
$$

where $c_{0}, c_{1}, c_{2}$, and $c_{3}$ are coefficients of the thirdorder orthogonal Legendre polynomial at DIM $d$, and $w$ is coefficient of the exponential term of the Wilmink function (Wilmink, 1987). The most appropriate coefficient of the exponential term $w$ that fitted the current data for modeling the fixed lactation curves for FPR and test-day SCS was estimated to be -0.05 (Negussie et al., 2008). The regression coefficients (b) describe the shape of the lactation curve within calving-year $\times$ calving-season classes. The 3 calving seasons were October to February, March to June, and July to September. In Finland, herd sizes are small and, therefore, the herd effect was modeled by fixed herd-year and random herd-test-day $(h t d)$ components.

The covariance structure for models was defined as

$$
\operatorname{Var}\left[\begin{array}{l}
\mathbf{h t d} \\
\mathbf{a} \\
\mathbf{p} \\
\mathbf{e}
\end{array}\right]=\left[\begin{array}{cccc}
\mathbf{H} \otimes \mathbf{I} & 0 & 0 & 0 \\
0 & \mathbf{G} \otimes \mathbf{A} & 0 & 0 \\
0 & 0 & \mathbf{P} \otimes \mathbf{I} & 0 \\
0 & 0 & 0 & \mathbf{R} \otimes \mathbf{I}
\end{array}\right],
$$

where $\mathbf{H}$ is a diagonal matrix having variances of the random $h t d$ effects for FPR and SCS or MY for model II and $\mathbf{H}$ is $\mathbf{I} \sigma_{h}^{2}$ for model I, $\mathbf{A}$ is the matrix of additive genetic relationships among sires, $\otimes$ is the Kronecker product, $\mathbf{G}$ and $\mathbf{P}$ are covariance matrices of the random regression coefficients for sire additive genetic and cow permanent environmental effects, respectively, and $\mathbf{R}$ is the residual covariance matrix.

In the bivariate RRM analyses of FPR and fertility traits, random genetic effects were $\mathbf{a}_{F P R}$ and $\mathbf{a}_{T}$. The $\mathbf{a}_{F P R}$ had random genetic effects for test-day FPR with

$$
\boldsymbol{\varphi}_{\alpha}(d)=\left[\begin{array}{lll}
c_{0} & c_{1} & c_{2}
\end{array}\right]^{\prime},
$$

representing a second-order orthogonal Legendre polynomial at DIM $d$. Likewise, random effects $\mathbf{p}_{F P R}$ and $\mathbf{p}_{T}$ were nongenetic animal effects for a cow $m$ with $\varphi_{\alpha}(d)$ as in [2] for test-day FPR, and fertility traits, respectively. Random $e_{F P R}$ and $e_{T}$ were measurement errors. The residual covariance between the longitudinal trait FPR and the lactation-wise fertility or CM traits were assumed to be zero or uncorrelated because they were not observed at the same time. In addition, for computational reasons, a homogeneous residual variance structure was assumed for the test-day traits. Details of the methods used for the estimation of variance components in bivariate analyses involving traits with different data structures have been described previously (Mäntysaari, 2006; Negussie et al., 2008). All analyses were made using average information-REML as implemented in the DMU package (Madsen and Jensen, 2006). Estimated covariance components of the random regression coefficients for sire additive genetic and cow permanent environmental effects were used to derive the daily heritabilities and genetic and phenotypic associations among the traits. Estimates of heritabilities for the different traits were calculated from univariate analyses, whereas estimates of correlations between 
traits for the same trait were averages of the bivariate analyses.

Estimation of Heritabilities and Correlations. Daily sire variance of a test-day trait (FPR or SCS) at time $d_{i}$ can be written as

$$
\sigma_{s}^{2}\left(d_{i}\right)=\varphi_{\alpha}^{\prime}\left(d_{i}\right) \mathbf{G}_{t} \boldsymbol{\varphi}_{\alpha}^{\prime}\left(d_{i}\right),
$$

where $\mathbf{G}_{t}$ is covariance matrix of the random sire regression coefficients for trait $t$ (FPR or SCS). Heritability of a trait at any time $d_{i}$ along the lactation trajectory was estimated as

$$
\hat{h}_{d_{i}}^{2}=4 \hat{\sigma}_{s}^{2}\left(d_{i}\right) /\left[\hat{\sigma}_{e}^{2}+\hat{\sigma}_{p}^{2}\left(d_{i}\right)+\hat{\sigma}_{s}^{2}\left(d_{i}\right)+\hat{\sigma}_{h}^{2}\right],
$$

where $\hat{\sigma}_{p}^{2}$ is the variance of permanent environmental effects for trait $t$ (FPR or SCS) given as $\left[\boldsymbol{\varphi}_{\alpha}^{\prime}\left(d_{i}\right) \mathbf{P}_{t} \boldsymbol{\varphi}_{\alpha}\left(d_{i}\right)\right]$, and $\mathbf{P}_{t}$ is covariance matrix of the permanent environment regression coefficients for trait $t$. Genetic correlations between test-day FPR and fertility or CM trait $t$ at times $d_{i}$ were estimated as:

$$
\hat{r}_{g}\left(d_{i}\right)=\frac{\boldsymbol{\varphi}_{\alpha}^{\prime}\left(d_{i}\right) \mathbf{G}_{F P R, t} \mathbf{1}}{\sqrt{\hat{\sigma}_{F P R}^{2}\left(d_{i}\right) \hat{\sigma}_{t}^{2}}},
$$

where $\mathbf{1}$ is a vector of ones, $\mathbf{G}_{F P R, t}$ is random regression coefficients of the genetic sire covariance between the test-day FPR and trait $t$ (fertility or CM), $\hat{\sigma}_{t}^{2}$ is the sire variance of trait $t$, and $\hat{\sigma}_{F P R}^{2}$ is the sire variance for FPR.

\section{RESULTS}

The plot of mean daily test-day FPR in first-lactation cows is shown in Figure 1. The mean test-day FPR in first-lactation cows was about 1.28 and ranged from 1.25 to 1.45 . In early lactation (from 8 to 40 DIM), the mean test-day FPR ranged from 1.32 to 1.42 and FPR declined toward mid lactation. Soon after mid lactation, a relative constancy was observed until 200 DIM, when FPR started to increase slightly toward the end of lactation. The lactation curves modeled for test-day FPR, MY, and SCS of first-lactation cows are in Figure 2a, b, and c, respectively. As shown in Figure 2a, FPR was highest in early lactation, stabilized in mid lactation (from 100 to 200 DIM), and increased slightly toward the end of the lactation period.

The heritabilities of test-day FPR and the different fertility traits and CM are given in Table 2. The heritability of fertility traits DFI, DO, NI, and NRR were $0.04,0.03,0.01$, and 0.02 , respectively. Most heritability estimates were statistically significant $(P<0.05$; Tables $2,3$, and 4$)$. For udder health, the heritability of $\mathrm{CM}$ in first-lactation Finnish Ayrshire was 0.02. Tables 3 and 4 present heritabilities of test-day FPR, MY, and SCS for selected DIM; daily heritabilities for these traits are given in Figure 3. During lactation, the heritability of test-day FPR was from 0.13 to $0.25(P<0.05)$. In early lactation (from 8 to 50 DIM), heritability of FPR ranged from 0.13 to 0.20 . Starting from DIM 50, the heritability of FPR increased gradually and reached its peak of 0.25 by late mid lactation (170 DIM), where it stabilized until 270 DIM and declined to about 0.23 toward the end of lactation.

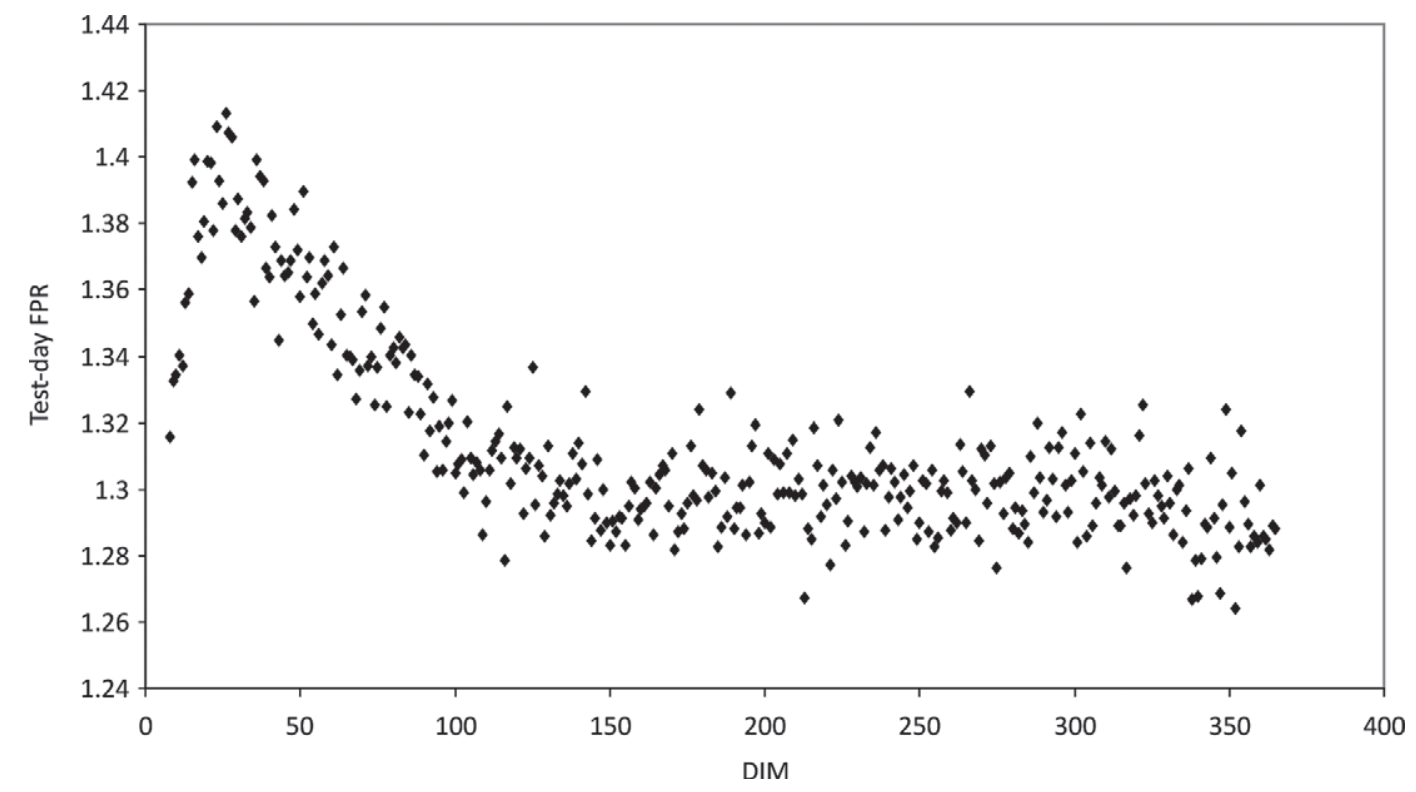

Figure 1. Average daily milk fat to protein ratio (FPR) during first lactation. 

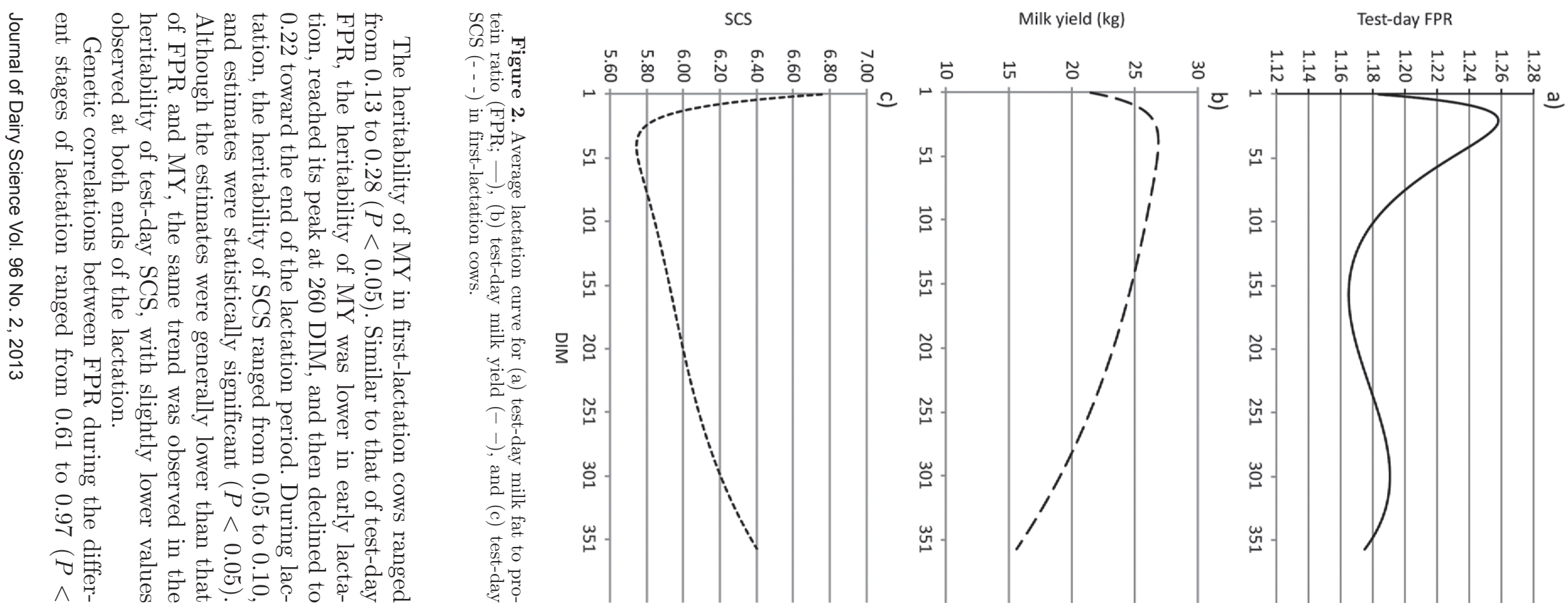

$\mathfrak{v}$

옵

它

믈 옹.

$\stackrel{N}{\oplus}$

$\stackrel{\omega}{\circ}$

$\underset{\sim}{\stackrel{w}{心}}$

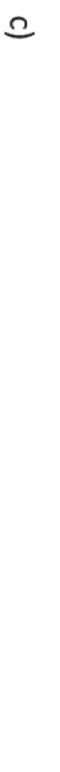

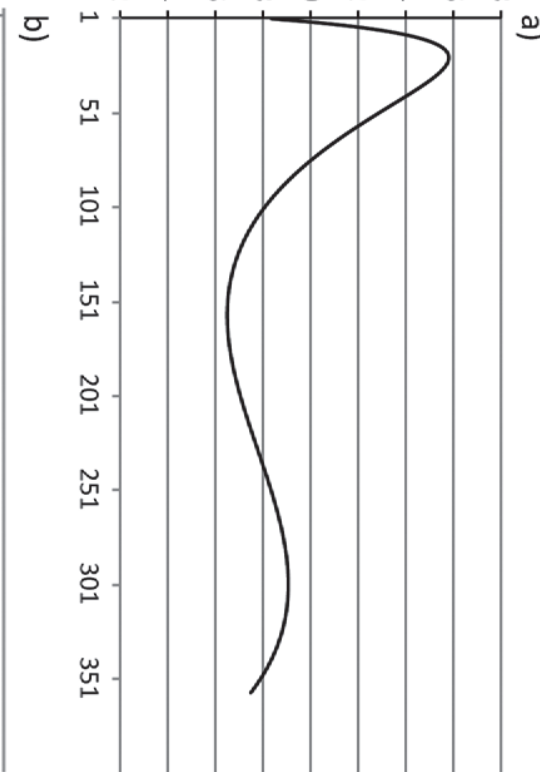

E

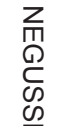

Table 2. Heritability (diagonal) ${ }^{1}$ and genetic correlation (below diagonal) ${ }^{2}$ and phenotypic correlation (above diagonal) ${ }^{3}$ between test-day milk fat:protein ratio (FPR) and fertility traits calving to first insemination (DFI), days open (DO), number of inseminations (NI), nonreturn rate to $56 \mathrm{~d}$ (NRR), and clinical mastitis (CM) for selected DIM

FPR at DIM

\begin{tabular}{|c|c|c|c|c|c|c|c|c|c|c|c|c|}
\hline Trait & 30 & 60 & 110 & 160 & 210 & 260 & 310 & DFI & DO & NI & NRR & $\mathrm{CM}$ \\
\hline \multicolumn{13}{|c|}{ FPR at DIM } \\
\hline 30 & $0.16^{*}$ & $0.49^{*}$ & $0.35^{*}$ & 0.22 & 0.16 & 0.13 & 0.12 & 0.05 & 0.05 & 0.04 & -0.03 & -0.01 \\
\hline 60 & $0.96^{*}$ & $0.19^{*}$ & $0.38^{*}$ & $0.29 *$ & 0.22 & 0.18 & 0.16 & 0.04 & 0.04 & 0.03 & -0.02 & -0.01 \\
\hline 110 & $0.87^{*}$ & $0.97^{*}$ & $0.23^{*}$ & $0.35^{*}$ & $0.30^{*}$ & $0.26^{*}$ & 0.22 & 0.02 & 0.02 & 0.02 & -0.01 & -0.02 \\
\hline 160 & $0.79^{*}$ & $0.92^{*}$ & $0.99^{*}$ & $0.25 *$ & $0.35^{*}$ & $0.31^{*}$ & 0.26 & 0.01 & 0.01 & 0.01 & -0.01 & -0.02 \\
\hline 210 & $0.71^{*}$ & $0.86^{*}$ & $0.95^{*}$ & $0.99 *$ & $0.25^{*}$ & $0.34^{*}$ & $0.28^{*}$ & -0.02 & -0.02 & -0.01 & 0.02 & -0.03 \\
\hline 260 & $0.66^{*}$ & $0.81^{*}$ & $0.91^{*}$ & $0.96^{*}$ & $0.99^{*}$ & $0.25 *$ & $0.30^{*}$ & -0.04 & -0.04 & -0.03 & 0.03 & -0.03 \\
\hline 310 & $0.61^{*}$ & $0.74^{*}$ & $0.82^{*}$ & $0.88^{*}$ & $0.93^{*}$ & $0.98^{*}$ & $0.24^{*}$ & -0.06 & -0.06 & -0.04 & 0.04 & -0.03 \\
\hline DFI & $0.28^{*}$ & $0.14^{*}$ & 0.05 & -0.01 & -0.04 & -0.04 & -0.01 & 0.04 & & \multirow{5}{*}{0.01} & & \\
\hline DO & $0.24^{*}$ & $0.19^{*}$ & 0.13 & 0.09 & 0.05 & 0.03 & 0.03 & & 0.03 & & \multirow{4}{*}{0.02} & \\
\hline NI & 0.03 & 0.02 & -0.01 & -0.01 & -0.09 & -0.15 & -0.21 & & & & & \multirow[b]{3}{*}{0.02} \\
\hline NRR & 0.01 & 0.01 & 0.02 & 0.04 & 0.06 & 0.09 & 0.12 & & & & & \\
\hline $\mathrm{CM}$ & $0.19^{*}$ & $0.21^{*}$ & $0.21^{*}$ & 0.20 & 0.18 & 0.16 & 0.12 & & & & & \\
\hline
\end{tabular}

${ }^{1}$ Estimates of heritabilities are from single-trait analyses. Standard errors ranged from 0.02 to $0.06,0.006$ to 0.01 , and 0.004 for test-day FPR, fertility, and CM traits, respectively ${ }^{2}$ Standard errors of genetic correlations within FPR are average estimates and ranged from 0.04 to 0.10. Standard errors of genetic correlations between FPR and fertility and between FPR and CM traits ranged from 0.004 to 0.01 and from 0.01 to 0.09 , respectively.

${ }^{3}$ Standard errors of phenotypic correlations within FPR are average estimates and ranged from 0.03 to 0.08 . Standard errors for phenotypic correlations between FPR and fertility and between FPR and CM traits ranged from 0.002 to 0.01 and 0.002 to 0.02 , respectively. $* P<0.05$. 
Table 3. Heritability (on diagonal), ${ }^{1}$ genetic (below diagonal), ${ }^{2}$ and phenotypic correlation (above diagonal) ${ }^{3}$ between test-day milk fat:protein ratio (FPR) and milk yield (MY) for selected DIM

\begin{tabular}{|c|c|c|c|c|c|c|c|c|c|c|c|c|c|c|}
\hline \multirow[b]{2}{*}{ Trait } & \multicolumn{7}{|c|}{ MY at DIM } & \multicolumn{7}{|c|}{ FPR at DIM } \\
\hline & 30 & 60 & 110 & 160 & 210 & 260 & 310 & 30 & 60 & 110 & 160 & 210 & 260 & 310 \\
\hline \multicolumn{15}{|c|}{ MY at DIM } \\
\hline $30^{a}$ & $0.15^{*}$ & $0.69^{*}$ & $0.61^{*}$ & $0.53^{*}$ & $0.45^{*}$ & 0.38 & 0.28 & 0.02 & 0.01 & -0.01 & -0.03 & -0.04 & -0.05 & -0.06 \\
\hline 60 & $0.98^{*}$ & $0.18^{*}$ & $0.68^{*}$ & $0.63^{*}$ & $0.56^{*}$ & $0.46^{*}$ & 0.31 & 0.02 & 0.01 & -0.02 & -0.04 & -0.06 & -0.07 & -0.07 \\
\hline 110 & $0.93^{*}$ & $0.98^{*}$ & $0.22 *$ & $0.71^{*}$ & $0.66^{*}$ & $0.55^{*}$ & $0.37^{*}$ & 0.03 & 0.01 & -0.02 & -0.05 & -0.07 & -0.08 & -0.08 \\
\hline 160 & $0.87^{*}$ & $0.94^{*}$ & $0.99^{*}$ & $0.24^{*}$ & $0.71^{*}$ & $0.62^{*}$ & $0.44^{*}$ & 0.03 & 0.01 & -0.02 & -0.05 & -0.07 & -0.08 & -0.09 \\
\hline 210 & $0.80^{*}$ & $0.88^{*}$ & $0.95^{*}$ & $0.98^{*}$ & $0.27^{*}$ & $0.71^{*}$ & $0.57^{*}$ & 0.04 & 0.02 & -0.02 & -0.05 & -0.07 & -0.08 & -0.09 \\
\hline 260 & $0.70^{*}$ & $0.78^{*}$ & $0.86^{*}$ & $0.91 *$ & $0.97^{*}$ & $0.28^{*}$ & $0.73^{*}$ & 0.05 & 0.03 & 0.01 & -0.03 & -0.06 & -0.07 & -0.08 \\
\hline 310 & $0.58^{*}$ & $0.63^{*}$ & $0.70^{*}$ & $0.77^{*}$ & $0.87^{*}$ & $0.96^{*}$ & $0.25 *$ & 0.05 & 0.04 & 0.01 & -0.01 & -0.03 & -0.05 & -0.08 \\
\hline \multicolumn{15}{|c|}{ FPR at DIM } \\
\hline 30 & $0.13^{*}$ & 0.08 & 0.02 & -0.01 & -0.03 & -0.02 & 0.01 & $0.16^{*}$ & $0.49^{*}$ & $0.35^{*}$ & 0.22 & 0.16 & 0.13 & 0.12 \\
\hline 60 & 0.06 & 0.01 & -0.05 & -0.08 & -0.09 & -0.07 & -0.03 & $0.96^{*}$ & $0.19 *$ & $0.38^{*}$ & $0.29^{*}$ & 0.22 & 0.18 & 0.16 \\
\hline 110 & -0.02 & -0.07 & -0.12 & -0.15 & -0.15 & -0.12 & -0.07 & $0.87^{*}$ & $0.97^{*}$ & $0.23^{*}$ & $0.35^{*}$ & $0.30^{*}$ & $0.26^{*}$ & 0.22 \\
\hline 160 & -0.07 & -0.13 & -0.17 & -0.19 & -0.19 & -0.15 & -0.09 & $0.79^{*}$ & $0.92^{*}$ & $0.99^{*}$ & $0.25^{*}$ & $0.35^{*}$ & $0.31^{*}$ & 0.26 \\
\hline 210 & -0.12 & -0.17 & -0.22 & -0.23 & -0.22 & -0.18 & -0.11 & $0.71^{*}$ & $0.86^{*}$ & $0.95^{*}$ & $0.99^{*}$ & $0.25 *$ & $0.34^{*}$ & $0.28^{*}$ \\
\hline 260 & -0.15 & -0.20 & -0.24 & -0.25 & -0.24 & -0.19 & -0.11 & $0.66^{*}$ & $0.81^{*}$ & $0.91^{*}$ & $0.96^{*}$ & $0.99^{*}$ & $0.25 *$ & $0.30^{*}$ \\
\hline 310 & -0.17 & -0.21 & -0.25 & -0.25 & -0.24 & -0.18 & -0.11 & $0.61^{*}$ & $0.74^{*}$ & $0.82^{*}$ & $0.88^{*}$ & $0.93^{*}$ & $0.98^{*}$ & $0.24^{*}$ \\
\hline
\end{tabular}

${ }^{1}$ Estimates of heritabilities are from single-trait analyses. Standard error for MY ranged from 0.01 to 0.06 and those for test-day FPR ranged from 0.02 to 0.06.

${ }^{2}$ Standard errors of genetic correlations within FPR are average estimates and ranged from 0.04 to 0.10 , for within MY ranged from 0.02 to 0.09 . Standard errors of genetic correlac tions between MY and FPR ranged from 0.009 to 0.01 .

$\stackrel{\circ}{3}$ Standard errors of phenotypic correlations within FPR are average estimates and ranged from 0.03 to 0.08 and standard errors of correlations between MY and FPR ranged from 0.003 to 0.02

$\stackrel{0}{\circ} \quad *<0.05$. 
Table 4. Heritability (on diagonal), ${ }^{1}$ genetic (below diagonal), ${ }^{2}$ and phenotypic correlation (above diagonal) ${ }^{3}$ between test-day milk fat:protein ratio (FPR) and test-day SCS for selected DIM

\begin{tabular}{|c|c|c|c|c|c|c|c|c|c|c|c|c|c|c|}
\hline \multirow[b]{2}{*}{ Trait } & \multicolumn{7}{|c|}{ SCS at DIM } & \multicolumn{7}{|c|}{ FPR at DIM } \\
\hline & 30 & 60 & 110 & 160 & 210 & 260 & 310 & 30 & 60 & 110 & 160 & 210 & 260 & 310 \\
\hline \multicolumn{15}{|c|}{ SCS at DIM } \\
\hline 30 & $0.06^{*}$ & $0.54^{*}$ & 0.28 & 0.15 & 0.07 & 0.03 & 0.03 & 0.07 & 0.03 & 0.00 & -0.02 & -0.03 & -0.04 & -0.03 \\
\hline 60 & $0.95^{*}$ & $0.07^{*}$ & $0.37^{*}$ & $0.28^{*}$ & 0.21 & 0.15 & 0.11 & 0.05 & 0.03 & 0.01 & -0.01 & -0.03 & -0.03 & -0.03 \\
\hline 110 & $0.72^{*}$ & $0.90^{*}$ & $0.08^{*}$ & $0.50^{*}$ & $0.47^{*}$ & $0.41^{*}$ & 0.30 & 0.02 & 0.02 & 0.01 & 0.00 & -0.01 & -0.02 & -0.03 \\
\hline 160 & $0.63^{*}$ & $0.83^{*}$ & $0.99^{*}$ & $0.09^{*}$ & $0.53^{*}$ & $0.48^{*}$ & $0.38^{*}$ & 0.01 & 0.01 & 0.01 & 0.01 & 0.00 & -0.01 & -0.03 \\
\hline 210 & $0.57^{*}$ & $0.79^{*}$ & $0.98^{*}$ & $0.99 *$ & $0.09 *$ & $0.52^{*}$ & $0.44^{*}$ & -0.00 & 0.01 & 0.01 & 0.01 & 0.00 & -0.01 & -0.02 \\
\hline 260 & $0.53^{*}$ & $0.75^{*}$ & $0.96^{*}$ & $0.98^{*}$ & $0.99^{*}$ & $0.09 *$ & $0.49^{*}$ & -0.00 & 0.00 & 0.00 & -0.00 & -0.00 & -0.01 & -0.02 \\
\hline 310 & 0.50 & $0.72^{*}$ & $0.92^{*}$ & $0.96^{*}$ & $0.97^{*}$ & $0.99^{*}$ & $0.07^{*}$ & 0.00 & 0.00 & -0.01 & -0.01 & -0.01 & -0.01 & -0.01 \\
\hline \multicolumn{15}{|c|}{ FPR at DIM } \\
\hline 30 & $0.20^{*}$ & $0.13^{*}$ & 0.02 & 0.00 & 0.01 & 0.04 & 0.10 & $0.16^{*}$ & $0.49^{*}$ & $0.35^{*}$ & 0.22 & 0.16 & 0.13 & 0.12 \\
\hline 60 & 0.06 & 0.04 & 0.02 & 0.02 & 0.03 & 0.06 & 0.11 & $0.96^{*}$ & $0.19^{*}$ & $0.38^{*}$ & $0.29^{*}$ & 0.22 & 0.18 & 0.16 \\
\hline 110 & -0.03 & -0.02 & 0.01 & 0.03 & 0.05 & 0.07 & 0.11 & $0.87^{*}$ & $0.97^{*}$ & $0.23^{*}$ & $0.35^{*}$ & $0.30^{*}$ & $0.26^{*}$ & 0.22 \\
\hline 160 & -0.08 & -0.05 & 0.01 & 0.03 & 0.05 & 0.07 & 0.10 & $0.79^{*}$ & $0.92^{*}$ & $0.99^{*}$ & $0.25^{*}$ & $0.35^{*}$ & $0.31^{*}$ & 0.26 \\
\hline 210 & -0.10 & -0.07 & -0.01 & 0.02 & 0.04 & 0.05 & 0.07 & $0.71^{*}$ & $0.86^{*}$ & $0.95^{*}$ & $0.99^{*}$ & $0.25^{*}$ & $0.34^{*}$ & $0.28^{*}$ \\
\hline 260 & -0.09 & -0.07 & -0.01 & 0.01 & 0.02 & 0.03 & 0.04 & $0.66^{*}$ & $0.81^{*}$ & $0.91^{*}$ & $0.96^{*}$ & $0.99^{*}$ & $0.25^{*}$ & $0.30^{*}$ \\
\hline 310 & -0.05 & -0.04 & -0.03 & -0.02 & -0.02 & -0.01 & -0.01 & $0.61^{*}$ & $0.74^{*}$ & $0.82^{*}$ & $0.88^{*}$ & $0.93^{*}$ & $0.98^{*}$ & $0.24^{*}$ \\
\hline
\end{tabular}

${ }^{1}$ Estimates of heritabilities are from single-trait analyses. Standard errors for test-day SCS ranged from 0.004 to 0.01 and those for test-day FPR ranged from 0.02 to 0.06.

${ }^{2}$ Standard errors of genetic correlations for within FPR are average estimates and ranged from 0.04 to 0.10 and for within SCS ranged from 0.04 to 0.09. Standard errors of genetic correlations between SCS and FPR ranged from 0.008 to 0.01 .

${ }^{3}$ Standard errors of phenotypic correlations for within FPR are average estimates and ranged from 0.03 to 0.08 and within SCS ranged from 0.006 to 0.01 . Standard errors of phenotypic correlations between FPR and SCS ranged from 0.004 to 0.02 .

$* P<0.05$. 


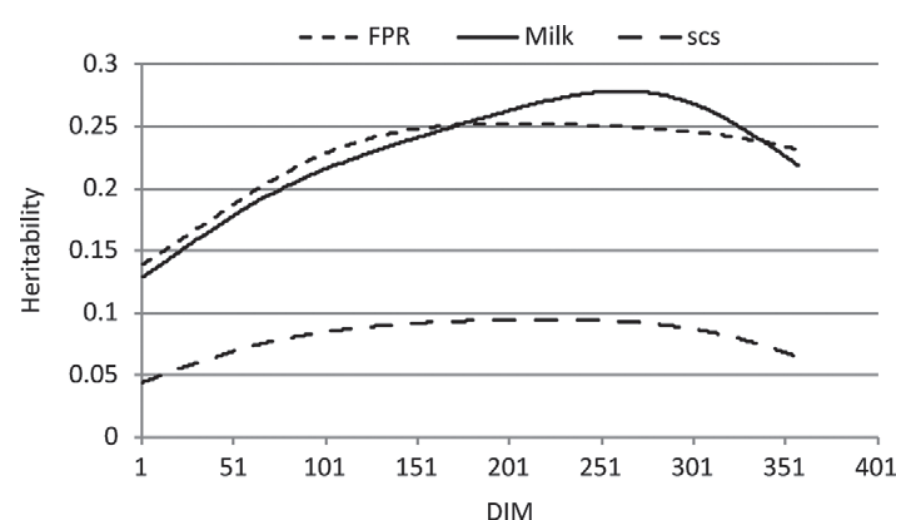

Figure 3. Heritability $\left(\mathrm{h}^{2}\right)$ of test-day milk fat to protein ratio (FPR; - - , SE $=0.02$ to 0.06 ), milk yield (-, SE $=0.01$ to 0.06$)$, and SCS $(--, \mathrm{SE}=0.004$ to 0.01$)$ during first lactation.

0.05), indicating that FPR in early lactation and in mid to late lactation are not exactly the same traits. The genetic and phenotypic correlations between test-day FPR and MY for selected DIM are shown in Table 3. Daily genetic correlations between test-day FPR, MY, and SCS are in Figure 4. Genetic correlations in early lactation between test-day FPR and MY at 15, 30, and 60 DIM were small but positive and ranged from 0.01 to $0.13(P<0.05$ at DIM 30). After 60 DIM, however, these correlations were mostly negative and ranged from 0.01 to $-0.22(P>0.05)$.

Genetic correlations between test-day FPR and fertility traits are shown in Table 2. The correlations between FPR and fertility traits varied depending on the particular fertility trait and the stage of lactation considered. For instance, genetic correlations between FPR and the fertility traits DFI and DO were generally positive and higher in early lactation from 8 to 60 DIM (early lactation daily estimates not shown) compared with the estimates in mid to late lactation.

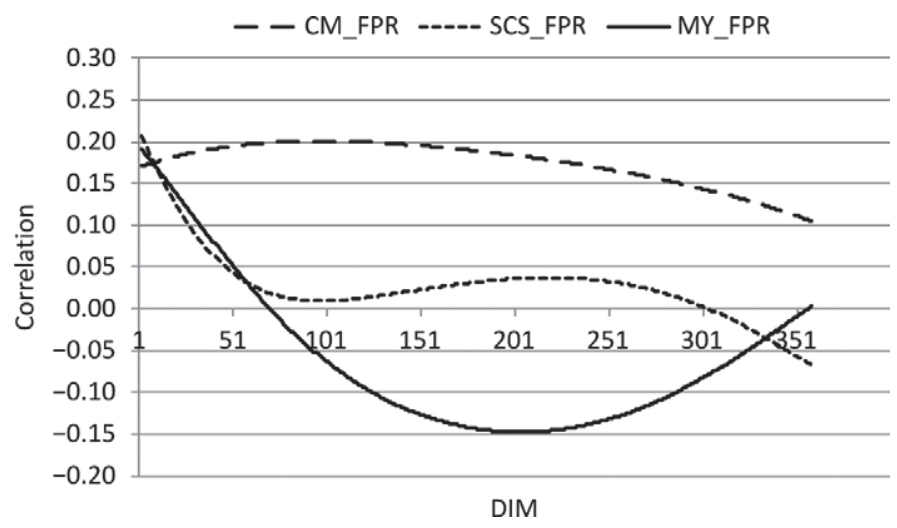

Figure 4. Genetic correlation between milk fat to protein ratio (FPR) and clinical mastitis (CM_FPR,,$-- \mathrm{SE}=0.01$ to 0.009), FPR and SCS (SCS_FPR, - - , SE $=0.008$ to 0.01 ), and FPR and milk yield (MY_FPR, —, $\mathrm{SE}=0.009$ to 0.01 ) during first lactation.
In early lactation, correlations between FPR and DFI and between FPR and DO ranged from 0.14 to $0.28(P$ $<0.05)$ and from 0.19 to $0.24(P<0.05)$, respectively. These correlations became generally small and negative in mid to late lactation, ranging from -0.01 to 0.09 . In both cases, the highest correlations between DO and DFI with FPR were observed in early lactation from calving to 40 DIM, whereas the lowest correlations of 0.01 to 0.09 were observed from the middle toward the end of the lactation period.

Genetic correlations between test-day FPR and the fertility trait NI were small and nonsignificantly different from zero $(P>0.05)$ and ranged from 0.02 to 0.03 in early lactation until 60 DIM (Table 2). After 60 DIM, however, these correlations were negative and increased from -0.01 to -0.21 by the end of lactation. A somewhat similar trend was observed for the genetic correlation between test-day FPR and NRR. Genetic correlations between FPR and NRR were also nonsignificantly different from zero $(P>0.05)$ and ranged from 0.01 to 0.02 in early lactation. After mid lactation, correlations gradually increased from 0.01 to 0.12 toward the end of lactation.

The genetic correlation between test-day FPR and udder health trait CM is shown in Table 2. Genetic correlations between FPR and CM were positive during lactation, even though the strength of the correlation varied with stage of lactation. In early lactation, until 60 DIM, correlations between the 2 traits were significant $(P<0.05)$ and ranged from 0.19 to 0.21 . By mid lactation, the correlation was around 0.20 and decreased gradually toward the end of the lactation period (Figure 4).

The genetic correlations between test-day FPR and another udder health trait SCS for selected DIM are given in Table 4. Similar to CM, genetic correlations between these 2 traits were also positive during the lactation and the strength of the correlation varied during lactation (Figure 4). Correlations were, in general, higher in early lactation than in mid or late lactation. For instance, in early lactation until 60 DIM, correlations between FPR and SCS were significant $(P<$ 0.05 ) and ranged from 0.09 to 0.20 . As lactation progressed, these correlations between test-day FPR and SCS declined from 0.20 at 1 mo after calving to almost zero by 100 DIM. After 100 DIM, however, correlations increased slightly to about 0.05 before turning negative toward the end of the lactation.

\section{DISCUSSION}

\section{Mean FPR During Lactation}

During early lactation, the mean FPR in first-lactation cows varied between 1.25 and 1.45. In the litera- 
ture, mean test-day FPR varies greatly over lactation for different breeds and also during different stages of lactation. Working on data from Czech Holstein cows, Čejna and Chládek (2005) reported that FPR varied during lactation and that the highest values were observed at the beginning of lactation, with FPR ranging between 1.2 and 1.4. In German Holstein, Buttchereit et al. (2010) also observed that the highest FPR was recorded in early lactation but then stabilized to an average of 1.10 in primiparous cows recorded from 11 to 180 DIM. Similarly, for Canadian Holstein, Jamrozik and Schaeffer (2012) reported that test-day FPR ranged from 1.1 to 1.3 during first lactation. Working on 1,933 first-lactation test-day milk records of Holstein pooled from the Netherlands, Scotland, Sweden, and Ireland, Bastiaansen et al. (2010) reported, across all cows, a 305-d average FPR of 1.19 with the mean and maximum FPR of 1.30 and 1.45 for wk 2 to 5 of lactation, respectively. In a study involving Danish Holstein, Danish Red, and Jerseys, Friggens et al. (2007) also showed that FPR in early lactation ranged from 1.2 to 1.6 for the different breeds, with the highest values observed for Danish Holstein.

Negative energy balance and the accompanying increase in FPR underlying the early phase of lactation have been associated with several different metabolic and functional ailments in dairy cows. Heuer et al. (1999) indicated that cows with FPR >1.5 had higher risk of ketosis, displaced abomasum, ovarian cyst, lameness, and mastitis. They also indicated that such cows produced more milk but had poor reproductive performance, indicating the link between FPR, energy balance, and cow fertility. Similarly, working on data from Italian Holsteins, Toni et al. (2011) reported that cows in first lactation with an increased FPR were at a high risk of postmortem disease and eventual culling. They also reported that the culling rate was lowest among cows with an FPR of 1.0 to 1.5, and the rate increased with increasing value of the early postmortem FPR ratio. Therefore, at most critical stages of lactation, the follow-up and monitoring of FPR profile in dairy cows could provide a low-cost tool for identifying cows in NEB for on-farm decision making to avoid unfavorable consequences.

\section{Lactation Curves}

The lactation curve for MY was opposite to that of SCS (Figure 2b and c). In both FPR and SCS (Figure $2 \mathrm{a}$ and $2 \mathrm{c}$ ), the highest peak was in early lactation, which was followed by a decline as the lactation progressed and an increase toward the end of the lactation period.
In most studies, lactation curves so far reported for FPR showed relatively higher values in early lactation (Čejna and Chládek, 2005; Buttchereit et al., 2010; Jamrozik and Schaeffer, 2012) followed by a decline or stabilization toward the middle or end of lactation. In this study, however, the lactation curve for FPR showed 2 peaks similar to a bimodal distribution (Figure 2a), with the highest peak in early lactation (from 8 to 40 DIM) followed by a moderate peak toward the end of lactation (from 250 to 300 DIM). The first peak in early lactation could be related to the NEB and the consequent tissue mobilization associated with stresses of calving and peak milk production (Friggens et al., 2007; Buttchereit et al., 2010; Toni et al., 2011; Jamrozik and Schaeffer, 2012). The moderate peak observed toward the end of lactation could also be due to increased energy requirements by heavily pregnant cows to support milk production and advanced fetal growth. Such a trend of FPR during lactation has not been reported except in Buttchereit et al. (2010), who also noticed a slight increase in FPR toward the end of the lactation period in German Holstein. In transition cows, NEB that occurs toward the end of lactation and before parturition, when DMI declines, has also been reported (Grummer, 1995; Leslie, 2000). During this period, increased energy demand in late gestation and early lactation, combined with a decline in DMI before parturition, makes dairy cows exceptionally susceptible to a range of problems (Miksa et al., 2004).

Various functions have been used to model lactation curves for test-day traits (Ødegård et al., 2003; Lidauer et al., 2006; Negussie et al., 2008; Buttchereit et al., 2010). For instance, for test-day FPR, Buttchereit et al. (2010) compared 5 different lactation curve functions on German Holstein data. They suggested that AliSchaeffer (Ali and Schaeffer, 1987) is the best function to model the lactation curve of FPR in German Holstein and concluded that functions with fewer parameters cannot accurately model the variation of the lactation curve. In our study, lactation curves for the test-day traits and FPR were modeled by third-order Legendre polynomial and a Wilmink term. This is because in some cases, when only polynomials are used due to the global nature of polynomial fitting, individual observations exert an influence in unexpected ways on remote parts of the curve (Denison et al., 1998). To minimize this effect and model both ends of the lactation properly, we selected a combination of Legendre polynomials and a Wilmink term. Such combinations of functions for modeling lactation curves have the advantage of flexibility and numerical stability and are reported to model lactation curves in Finnish Ayrshire (Lidauer et al., 2003). Modeling lactation curves using 
a combination of Legendre polynomials and Wilmink function have also been reported for milk production (Lidauer et al., 2003) and SCS (Ødegård et al., 2003; Negussie et al., 2008).

\section{Heritabilities}

The size of heritability estimates differed among the test-day traits (Tables 3 and 4), and almost all estimates were statistically significant. However, we observed a general trend that heritabilities for both test-day FPR, MY, and SCS were slightly lower at both ends of the lactation trajectory and peaked around mid to late lactation. Such trends have also been reported for MY (Lidauer et al., 2003) in Finnish Ayrshire and for SCS (Ødegård et al., 2003; Negussie et al., 2006) in Finnish Ayrshire and Norwegian Red cattle, respectively.

For test-day FPR, the estimate of heritability from our study was slightly higher than the range of 0.14 to 0.19 reported for Austrian Simmental (Gredler et al., 2006) and Spanish Holstein (Peňa, 2006). Our estimates ranging from 0.14 to 0.25 , on the other hand, are lower than the range of 0.20 to 0.54 for German Holstein (Buttchereit et al., 2011) and that of 0.14 to 0.40 for Canadian Holstein (Jamrozik and Schaeffer, 2012). In this study, as well as in some of the previously mentioned studies, a sizable genetic variation for FPR was found. The slight differences in the size of the heritability estimates for FPR among the studies might be due to differences in the data, the breed studied, and the different types of models and effects included in the estimation models. The moderate heritability of FPR from our study shows that sizeable genetic variation exists for FPR in the Nordic Red cattle.

\section{Genetic Associations Between Test-Day FPR, MY, and Fertility}

Estimates of daily genetic correlation between FPR and MY are shown in Figure 4. The figure shows that correlations in early lactation were positive and decreased to zero after 65 DIM. The positive and significant genetic correlation (Table 3) in early lactation between test-day FPR and MY indicates that cows with high milk production have the propensity to mobilize body reserves to meet the high energy demands of peak lactation and hence a relatively higher FPR. After the peak milk production period, however, the genetic correlation between FPR and MY becomes close to zero or negative, which could suggest that cows may have come out of NEB. In some cows with excessive body tissue mobilization, coming out of NEB and regaining a positive energy balance status may take up to $20 \mathrm{wk}$
(Taylor et al., 2003). For Canadian Holstein, Jamrozik and Schaeffer (2012) reported a small but positive genetic correlations between MY and FPR until DIM 40 , which changed to stronger and negative correlation in mid to late lactation. Similarly, Buttchereit et al. (2011) showed that FPR and ECM were positively, albeit not significantly, correlated at the beginning of lactation, which is in line with our estimates of a small but positive correlation between FPR and MY in early first-lactation cows (Table 3).

Energy balance is the most important factor affecting reproductive efficiency after calving (Konigsson et al., 2008). Several studies have reported positive associations between EB and fertility postpartum (Von Farries, 1983; Grieve et al., 1986; Butler and Smith, 1989; Loeffler et al., 1999) at the phenotypic level. In particular, the resumption of ovarian activity is closely related to the metabolic or nutritional status of the cow. In the current study, the positive and significant genetic association in early lactation between fertility traits DFI and DO with FPR may indicate that cows with relatively higher FPR are also cows that tend to suffer from the unfavorable effects of NEB (Table 2). As a consequence, such cows tend to have longer intervals (in days) from calving to first insemination and from calving to conception. Besides, the lower and mostly negative genetic correlations between these traits in mid to late lactation may be an indication that $\mathrm{EB}$ in early and in mid to late lactation are somewhat different traits influenced by different sets of genes (Buttchereit et al., 2012).

One interesting result from this study is the difference in the strength and direction of genetic associations between FPR and fertility traits during early lactation. A closer look at the results shows 2 groups of fertility traits. The first group includes the interval fertility traits DFI and DO, whereas the second group includes the "success" fertility traits NI and NRR, which are primarily measures of success of conception. Our results indicated that in early lactation, FPR had a relatively stronger and significant genetic correlation with interval fertility traits (DFI and DO) than with the success fertility traits (NI and NRR; Table 2). Cows with relatively higher FPR in early lactation had longer DO and took longer from calving to first insemination. This relationship between interval fertility traits and FPR could be caused by the effect of NEB in early lactation on the endocrine status of the animal (which regulates ovarian function), which affects primarily the length of time from calving to the start of ovarian or luteal activity (Konigsson et al., 2008). Interval fertility traits measure this interval from calving to insemination and conception more accurately than do 
the success fertility traits; hence, the relatively stronger genetic correlations between FPR and interval fertility measures in early lactation.

On the other hand, genetic and phenotypic correlations between FPR and success fertility traits (NI and NRR) were low and mostly nonsignificant (Table 2). The lower genetic and phenotypic correlations between FPR and success fertility traits could be because these traits measure only the success of conception, perhaps because they are observed only after the cows have come out of NEB, gained condition, and started cycling. However, marked changes in the ratios of the milk components occur mainly during the early stages of lactation when the cows are mobilizing body reserves. Thus, these low genetic and phenotypic correlations between the success fertility traits and FPR during early lactation are expected.

\section{Genetic Associations Between Test-Day FPR and Udder Health Traits}

Banos et al. (2006) indicated additional gains expected when energy traits are considered along with udder health traits to improve robustness in dairy cows. Both Banos et al. (2006) and Lassen et al. (2003) reported genetic correlations of -0.16 between the energy trait BCS and the udder health trait CM in first-lactation cows. Understanding the direction and strength of genetic associations between other indicators of energy balance and udder health traits is essential. In this study, we considered genetic associations between FPR and udder health traits.

Genetic correlations between FPR and udder health traits CM and SCS were generally positive during early lactation (Table 2, Figure 4). This positive and significant genetic correlation between FPR and CM in early lactation (Table 2) could indicate that cows are increasingly susceptible to udder infections at times when their tissue EB status is compromised. It is also interesting to see that the genetic correlations during lactation between the 2 udder health traits and FPR had a similar trend, although the strength of the correlation varied during lactation (Figure 4). The slight difference in the strength of their association with FPR may be due to $\mathrm{CM}$ being a more direct measure of udder infection, and thus more sensitive to changes in tissue EB. Somatic cell score is an indicator of udder infection and its levels in milk have been used as proxy for mastitis because of the established genetic relationship between the 2 traits, ranging between 0.3 and 0.8 (Banos et al., 2006; Negussie, et al., 2006, 2008).

Several researchers have reported a strong association between NEB and subsequent occurrence of mastitis in dairy cows (Oltenacu and Ekesbo 1994; Pritchard, 2000; Lassen et al., 2003). Pritchard (2000) indicated that elevated blood ketone level from fat mobilization is one of the reasons for increased mastitis in early lactation cows. Similarly, SCC levels were also found to be higher in subclinical ketotic cows. Among cows that had elevated blood ketone levels for 2 or more weeks postpartum, over $21 \%$ had elevated SCC compared with only $13 \%$ of the cows without chronic elevated blood ketone levels.

So far, studies on genetic associations between FPR and other health traits such as metabolic problems are scarce. Particularly, literature reports on genetic associations between FPR and udder health traits during lactation in Nordic Red cattle are lacking. Among others, published studies include that of Buttchereit et al. (2012), who reported the relationship between CM and FPR for German Holstein, and Jamrozik and Schaeffer (2012), who presented the genetic association between test-day FPR and SCS, fitting a mixture model for Canadian Holstein.

Udder health is one of the most costly diseases in dairy cattle. Mastitis occurs with the highest frequency around parturition, and assessing the effect of periparturient and postpartum $\mathrm{EB}$ on udder health is important. Recent data suggest that the NEB that is accompanied by a reduction in feed intake around calving time is an important contributor to immunosuppression (Loor et al., 2006) and increased susceptibility to udder infection (Oltenacu and Ekesbo, 1994; Pritchard, 2000; Lassen et al., 2003). A better understanding of the associations between udder health and FPR corroborates the relationship between EB and host response to mastitis. This helps in devising strategies to modulate nutrition and management to reduce susceptibility to mastitis during critical phases of lactation.

\section{CONCLUSIONS}

Milk fat:protein ratio is an indicator of tissue EB that could be obtained from routine milk recording at no extra cost. The moderate positive genetic associations between FPR and interval fertility and udder health traits indicate that cows with relatively higher FPR tend to take longer to first insemination and have increased susceptibility to mastitis because of the negative EB and subsequent mobilization of body reserves characteristic of early lactation. Milk fat:protein ratio is a heritable trait, and its easy availability suggests its use as a low-cost tool to monitor for poor health and fertility during the critical phases of lactation as well as an important indicator trait to improve robustness in dairy cows through selection. 


\section{ACKNOWLEDGMENTS}

The authors thank the Finnish Animal Breeders Association (Faba, Vantaa, Finland) for providing the data and the Finnish Ministry of Agriculture and Forestry (Helsinki, Finland) for financial support.

\section{REFERENCES}

Ali, T. E., and L. R. Schaeffer. 1987. Accounting for covariances among test day milk yields in dairy cows. Can. J. Anim. Sci. 67:637-644.

Banos, G., M. P. Coffey, E. Wall, and S. Brotherstone. 2006. Genetic relationship between first-lactation body energy and later-life udder health in dairy cattle. J. Dairy. Sci. 89:2222-2232.

Bastiaansen, J. W. M., H. Bovenhuis, S. Wijga, S. Mc Parlandy, E. Wallz, E. Strandberg, and R. F. Veerkamp. 2010. Genomewide association study for milk production and fat to protein ratio in dairy cattle. Commun. No. 0270, pages 1-4 in Proc. 9th WCGALP, Leipzig, Germany.

Bauman, D. E., and W. B. Currie. 1980. Partitioning of nutrients during pregnancy and lactation: A review of mechanisms involving homeostasis and homeorhesis. J. Dairy Sci. 63:1514-1529.

Berry, D. P., F. Buckley, P. Dillon, R. D. Evans, M. Rath, and R. F. Veerkamp. 2003. Genetic parameters for body condition score, body weight, milk yield, and fertility estimated using random regression models. J. Dairy Sci. 86:3704-3717.

Butler, W. R., and R. D. Smith. 1989. Interrelationships between energy balance and postpartum reproductive function in dairy cattle. J. Dairy Sci. 72:767-783.

Buttchereit, N., E. Stamer, W. Junge, and G. Thaller. 2010. Evaluation of five lactation curve models fitted for fat-protein ratio of milk and daily energy balance. J. Dairy Sci. 93:1702-1712.

Buttchereit, N., E. Stamer, W. Junge, and G. Thaller. 2011. Short communication: Genetic relationships among daily energy balance, feed intake, body condition score, and fat to protein ratio of milk in dairy cows. J. Dairy Sci. 94:1586-1591.

Buttchereit, N., E. Stamer, W. Junge, and G. Thaller. 2012. Genetic parameters for energy balance, fat / protein ratio, body condition score and disease traits in German Holstein cows. J. Anim. Breed. Genet. 129:280-288. http://dx.doi.org/10.1111/j.14390388.2011.00976.x.

Čejna, V., and G. Chládek. 2005. The importance of monitoring changes in milk fat to protein ratio in Holstein cows during lactation. J. Cent. Europ. Agric. 6:539-545.

Coffey, M. P., G. C. Emmans, and S. Brotherstone. 2001. Genetic evaluations of dairy bulls for energy balance traits using random regression. J. Dairy Sci. 85:2669-2678.

Collard, B. L., P. J. Boettcher, J. C. M. Dekkers, D. Petitclerc, and L. R. Schaeffer. 2000. Relationships between energy balance and health traits of dairy cattle in early lactation. J. Dairy Sci. 83:2683-2690.

de Vries, M. J., and R. F. Veerkamp. 2000. Energy balance of dairy cattle in relation to milk production variables and fertility. J. Dairy Sci. 83:62-69.

Denison, D. G. T., B. K. Mallick, and A. F. M. Smith. 1998. Automatic Bayesian curve fitting. J. R. Stat. Soc., B 60:333-350.

Friggens, N. C., C. Ridder, and P. Lovendahl. 2007. On the use of milk composition measures to predict the energy balance of dairy cows. J. Dairy Sci. 90:5453-5467.

Gredler, B., C. Fuerst, and J. Sölkner. 2006. Genetic relationship between body condition score, days to first service and production traits in Austrian Simmental cattle. Commun. No. 11-05 in Proc. 8th World Congress on Genetics Applied to Livestock Production, Belo Horizonte, Brazil.

Grieve, D. G., S. Korver, Y. S. Rijpkema, and G. Hof. 1986. Relationship between milk composition and some nutritional parameters in early lactation. Livest. Prod. Sci. 14:239-254.
Grummer, R. R. 1995. Impact of changes in organic nutrient metabolism on feeding the transition dairy cow. J. Anim. Sci. 73:28202833.

Gürtler, H., and F. J. Schweigert. 2005. Physiologie der Laktation. Pages 552-573 in Physiologie der Haustiere. Vol. 2. W. von Engelhardt and G. Breves, ed. Enke Verlag, Stuttgart, Germany.

Heuer, C., Y. H. Schukken, and P. Dobbelaar. 1999. Postpartum body condition score and results from the first test day milk as predictors of disease, fertility, yield, and culling in commercial dairy herds. J. Dairy Sci. 82:295-304.

Jamrozik, J., and L. R. Schaeffer. 2012. Test-day somatic cell score, fat-to-protein ratio and milk yield as indicator traits for sub-clinical mastitis in dairy cattle. J. Anim. Breed. Genet. 129:11-19.

Kaufmann, W. 1979. Protein utilisation. Pages 90-113 in Feeding Strategy for the High Yielding Dairy Cow. W. H. Broster and H. Swan, ed. Granada, London, UK.

Konigsson, K., G. Savoini, N. Govoni, G. Invernizzi, A. Prandi, H. Kindahl, and M. C. Veronesi. 2008. Energy balance, leptin, NEFA and IGF-I plasma concentrations and resumption of postpartum ovarian activity in Swedish Red and White breed cows. Acta Vet. Scand. 50:3. http://dx.doi.org/10.1186/1751-0147-50-3.

Lassen, J., M. Hansen, M. K. Sørensen, G. P. Aamand, L. G. Christensen, and P. Madsen. 2003. Genetic relationship between body condition score, dairy character, mastitis, and diseases other than mastitis in first-parity Danish Holstein cows. J. Dairy Sci. $86: 3730-3735$.

Leslie, K. 2000. The influence of negative energy balance on udder health. National Mastitis Council Regional Meeting Proceedings. National Mastitis Council, Madison, WI.

Lidauer, M., E. A. Mäntysaari, and I. Strandén. 2003. Comparison of test-day models for genetic evaluation of production traits in dairy cattle. Livest. Prod. Sci. 79:73-86.

Lidauer, M., J. Pedersen, J. Pösö, E. Mäntysaari, I. Strandén, P. Madsen, U. Nielsen, J.-Å. Eriksson, K.-Å. Johansson, and G. Aamand. 2006. Joint Nordic test-day model: Evaluation model. Interbull Bull. 35:103-107.

Loeffler, S. H., M. J. deVries, and Y. H. Schukken. 1999. The effects of time of disease occurrence, milk yield, and body condition on fertility of dairy cows. J. Dairy Sci. 82:2589-2604.

Loker, S., C. Bastin, F. Miglior, A. Sewalem, L. R. Schaeffer, J. Jamrozik, and V. Osborne. 2011. Short communication: Estimates of genetic parameters of body condition score in the first 3 lactations using a random regression animal model. J. Dairy Sci. 94:36933699 .

Loor, J. J., H. M. Dann, R. E. Everts, R. Oliveira, C. A. Green, N. A. Janovick-Guretzky, N. Litherland, S. L. Rodriguez-Zas, H. A. Lewin, and J. K. Drackley. 2006. Plane of nutrition prepartum alters hepatic gene expression and function in dairy cows as assessed by longitudinal transcript and metabolic profiling. Physiol. Genomics 27:29-41.

Løvendahl, P., C. Ridder, and N. C. Friggens. 2010. Limits to prediction of energy balance from milk composition measures at individual cow level. J. Dairy Sci. 93:1998-2006.

Madsen, P., and J. Jensen. 2006. A User's Guide to DMU. A package for analysing multivariate mixed models. Version 6 , release 4.7. Danish Institute of Agricultural Sciences, Tjele, Denmark.

Mäntysaari, E. A. 2006. Meta model combines traits with different genetic models and data structures. CD-ROM Commun. no. 24-01 in Proc. 8th WCGALP, Belo Horizonte. Brazil.

Miksa, I. R., L. C. Buckley, and H. R. Poppenga. 2004. Detection of nonesterified (free) fatty acids in bovine serum: Comparative evaluation of two methods. J. Vet. Diagn. Invest. 16:139-144.

Negussie, E., M. Koivula, E. Mäntysaari, and M. Lidauer. 2006. Genetic evaluation of somatic cell score in dairy cattle considering first and later lactations as two different but correlated traits. J. Anim. Breed. Genet. 123:224-238.

Negussie, E., I. Strandén, and E. A. Mäntysaari. 2008. Genetic associations of clinical mastitis with test-day somatic cell count and milk yield during first lactation of Finnish Ayrshire. J. Dairy Sci. 91:1189-1197. 
Ødegård, J., J. Jensen, G. Klemetsdal, P. Madsen, and B. Heringstad. 2003. Genetic analysis of somatic cell score in Norwegian cattle using random regression test-day models. J. Dairy Sci. 86:41034114.

Oikonomou, G., G. E. Valergakis, G. Arsenos, N. Roubies, and G. Banos. 2008. Genetic profile of body energy and blood metabolic traits across lactation in primiparous Holstein cows. J. Dairy Sci. 91:2814-2822.

Oltenacu, P. A., and D. M. Broom. 2010. The impact of genetic selection for increased milk yield on the welfare of dairy cows. Anim. Welf. 19:39-49.

Oltenacu, P. A., and I. Ekesbo. 1994. Epidemiological study of clinical mastitis in dairy cattle. Vet. Res. 25:208-212.

Peňa, J. 2006. Genetic correlated traits for female fertility evaluation in Spanish Holstein. Interbull Bull. 34:31-33.

Pritchard, D. E. 2000. The association of inadequate energy intake at calving time with mastitis. Accessed Mar. 12, 2012. http:// www.cals.ncsu.edu/an_sci/extension/dairy/newsletters/0302nlet_ association.PDF.

Pryce, J. E., and R. F. Veerkamp. 2001. The incorporation of fertility indices in genetic improvement programs. Pages 223-236 in Fertility in the High-Producing Dairy Cow. M. G. Diskin, ed. Br. Soc. Anim. Sci. Occ. Publ. No. 26. Edinburgh, UK.

Reid, I. M., and C. J. Roberts. 1983. Subclinical fatty liver in dairy cows-Current research and future prospects. Ir. Vet. J. 37:104.
Sonstegard, T. S., C. P. Van Tassell, and M. S. Ashwell. 2001. Dairy cattle genomics: Tools to accelerate genetic improvement? J Anim. Sci. 79(E. Suppl.):E307-E315.

Taylor, V. J., D. E. Beever, and D. C. Wathes. 2003. Physiological adaptations to milk production that affect fertility in high yielding dairy cows. Pages 37-71 in Br. Soc. Anim. Sci. Occ. Publ. No. 29. Nottingham University Press, Nottingham, UK.

Thorup, V. M., D. Edwards, and N. C. Friggens. 2012. On-farm estimation of energy balance in dairy cows using only frequent body weight measurements and body condition score. J. Dairy Sci. 95:1784-1793.

Toni, F., L. Vincenti, L. Grigoletto, A. Ricci, and Y. H. Schukken. 2011. Early lactation ratio of fat and protein percentage in milk is associated with health, milk production, and survival. J. Dairy Sci. 94:1772-1783.

Veerkamp, R. F., E. P. C. Koenen, and G. De Jong. 2001. Genetic correlations among body condition score, yield and fertility in first parity cows estimated by random regression models. J. Dairy Sci. 84:2327-2335.

VonFarries, E. 1983. Stoffwechselstorungen und ihr Einfluss auf die Zusammensetzung der milch. Zuchtungskunde 55:265-274.

Wilmink, J. B. M. 1987. Adjustment of test-day milk, fat, and protein yields for age, season, and stage lactation. Livest. Prod. Sci. 16:335-348. 